\title{
Gastrointestinal protozoa and digestive tract parameters of wild South African warthogs (Phacochoerus aethiopicus)
}

\author{
D.G. Booyse' \& B.A. Dehority ${ }^{2 *}$ \\ ${ }^{1}$ Department of Anatomy and Physiology, University of Pretoria, Private Bag X04, \\ Onderstepoort, 0110 South Africa \\ ${ }^{2}$ Department of Animal Sciences, Ohio Agricultural Research and Development Center, \\ The Ohio State University, Wooster, OH 44691, U.S.A. \\ Received 2 June 2011. Accepted 26 October 2011
}

The warthog (Phacochoerus aethiopicus) is a grazer and hindgut fermenter with an apparent unique population of protozoa; however, only a limited number of specimens have been studied to date. In addition to having a very low number of protozoal species, little is known about temporal (seasonal) variation and geographic variation in protozoan diversity. Forty-one warthogs were harvested over a two-year period (2003-2005) from a wildlife area owned by the South African Air force (Ditholo). Additional samples were obtained from three animals at a farm near Northam (2004), plus three animals from a game ranch (Knapdaar) near Ellisras (2010). Several physical parameters of the digestive tract were measured, i.e. $\mathrm{pH}$, temperature, organ length, weight of organ contents, dry matter, density and digesta in vitro gas production. Samples were collected from the caecum and colon for protozoal counts. In the animals from Ditholo and Northam, Telamodinium onyx was present in 42 of the 44 animals and was the predominant species. Megadinium aethiopicum was observed in 33 animals and Teratodinium sphaeredon was present in 10 of the warthogs. Blepharoconus krugerensis was present in four animals. A single species of both Cyclopostidae and Isotricha were present in two separate animals. In the warthogs harvested at Knapdaar, T. onyx, M. aethiopicum and B. krugerensis were present in all three animals, while $M$. sphaeredon was present in only two. Unexpectedly, the species Blepharosphaera intestinalis and Charonina equi were found in all three animals. Concentration of protozoans in caecum/colon fluid averaged about $25 \times 10^{3}$ per $\mathrm{ml}$. In conclusion, the larger number of animals studied established that there can be considerable protozoan diversity among animals and that both seasonal and geographic variation occur.

Key words: gastrointestinal tract, hind-gut fermentation, Phacochoerus aethiopicus, Protozoa, South Africa, warthog.

The warthog (Phacochoerus aethiopicus) is a 1 grazer and hindgut fermenter with a unique population of protozoa (Hume \& Warner 1980;

*Author for correspondence. E-mail: dehority.1@osu.edu
Dehority 2003). In 1967, Latteur \& Dufey studied protozoa in the warthog hindgut, and reported a new subfamily, Telamodiniidae, in the family Spirodinidae, describing three new genera with a single species in each genus (Telamodinium onyx, Teratodinium sphaeredon and Megadinium aethiopicum). A second report by Van Hoven (1990), only mentioned that ciliate protozoa in the subfamily Telamodiniidae occurred in warthogs. More recently, in a study of 17 warthogs collected in South Africa, Booyse et al. (2010) reported the same three protozoan species as previously described by Latteur \& Dufey (1967). They attributed the low protozoan concentrations they found to be the result of limited nutritional value of forage available during the winter season.

In order to address the limitations (sample size and seasonality) of previous studies, the aim of the present study was to extend the sample size and include samples collected during different seasons of the year. By extending the sampling we hypothesized that additional species of protozoa, unique to the warthog, might be found. In addition, we report on several different parameters of the warthog digestive tract, including $\mathrm{pH}$, contents weight per organ, in vitro digesta gas production, dry matter and density of organ contents.

Samples were collected on a monthly basis during a two-year harvesting programme from 2003 through 2005 in the Ditholo private game reserve. The reserve is located $60 \mathrm{~km}$ north $\left(25^{\circ} 19^{\prime} 43.95^{\prime \prime} \mathrm{S}\right.$, $28^{\circ} 19^{\prime} 04.34^{\prime \prime} \mathrm{E}$ ) of Pretoria in the Limpopo Province of South Africa. Samples were obtained from 41 animals: 13 adult males, 16 adult females, two juvenile females, five subadult females, two juvenile males and three subadult males. Additional samples were also collected in June 2004 from three warthogs on a farm near the town of Northam in the North West Province, $150 \mathrm{~km}$ 

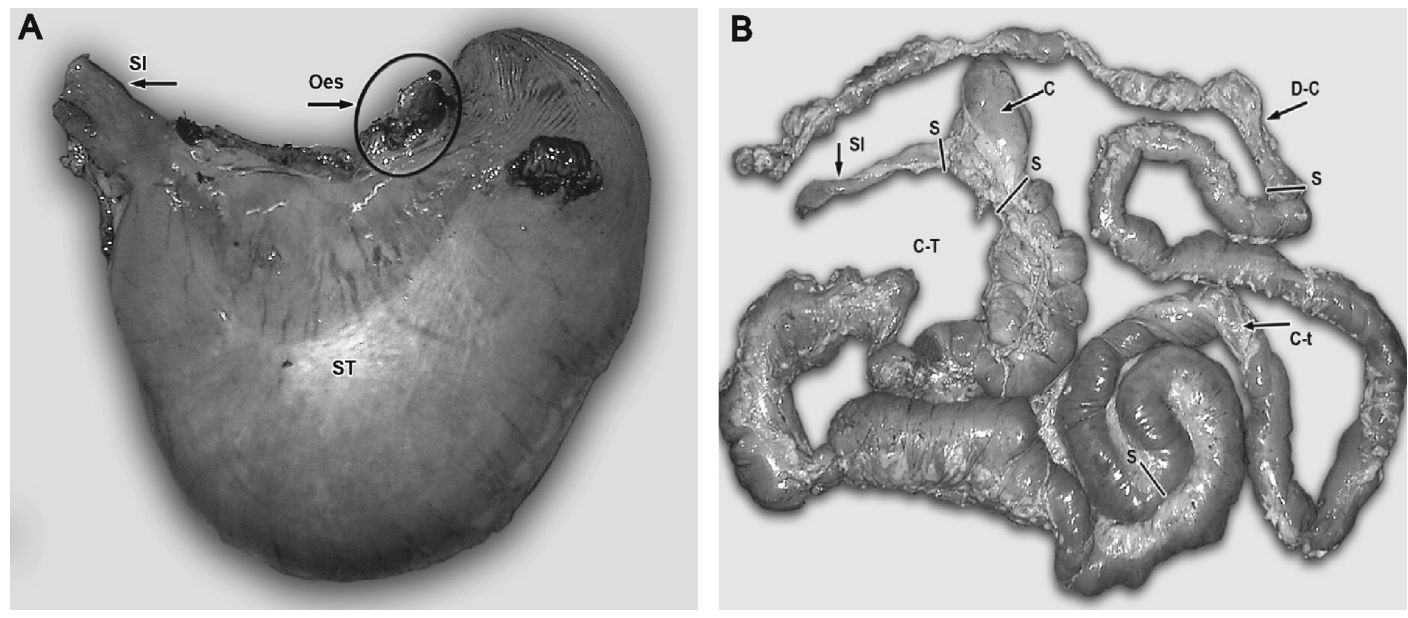

Fig. 1. A, Warthog stomach: Oes = oesophagus entrance, $\mathrm{ST}=$ stomach, $\mathrm{SI}=$ small intestine. Lengths ranged from 200-300 mm. B, Warthog intestinal tract: $C=$ caecum, D-C = descending colon, $C-T=$ colon (thick), $C-t=$ colon (thin), $\mathrm{S}=$ site of ligatures. Measurements: small intestine $=4410-7600 \mathrm{~mm}$; colon (thick) $=520-2200 \mathrm{~mm}$; colon (thin) = 510-1700; descending colon $=770-4480 \mathrm{~mm}$.

northwest $\left(24^{\circ} 57^{\prime} 47.59^{\prime \prime} \mathrm{S}, 27^{\circ} 15^{\prime} 52.84^{\prime \prime} \mathrm{E}\right)$ of Pretoria and in September 2010, three warthogs from the Knapdaar private game reserve, $350 \mathrm{~km}$ north $\left(23^{\circ} 30^{\prime} 09.46^{\prime \prime} S, 27^{\circ} 38^{\prime} 49.09^{\prime \prime} \mathrm{E}\right)$ of Pretoria, just north of the town of Ellisras. Based on visual observations by park rangers, animals were classified as juveniles, ranging from suckling up to six months old, as subadults, from six months up to one year old and adult, when older than one year (Table 1).

Samples of the different organ contents were collected from the animals within 40 minutes of having been shot. The stomach and whole intestinal tract were removed and the different sections were ligated and separated. Photographs and measurements of the digestive tract are shown in Fig. 1. Five $40-\mathrm{ml}$ samples $(200 \mathrm{ml}$ total) were taken at random from the stomach, small intestine, caecum and anterior portion of the colon (labelled colon thick) using a $40 \mathrm{ml}$ plastic container. These samples were used to measure dry matter and gas production. Fluid for protozoa counts was obtained by squeezing handfuls of the contents and collecting $200 \mathrm{ml}$ of fluid from the contents of each organ. The samples for protozoa counts were preserved by adding an equal volume of $70 \%$ ethanol.

Contents weight for each organ was estimated

Table 1. Age, sex and weight of the 47 African warthogs (Phacochoerus aethiopicus) sampled.

\begin{tabular}{lllcc}
\hline Age & Sex & No. & Weight $(\mathrm{kg}) \pm$ S.D. & Range $(\mathrm{g})$ \\
\hline Ditholo & & & & \\
Adult & Female & 16 & $51.3 \pm 9.1^{\mathrm{a}}$ & $39-67$ \\
& Male & 13 & $68.0 \pm 17.6^{\mathrm{b}}$ & $45-103$ \\
Subadult & Female & 5 & $24.2 \pm 14.2$ & $7.5-44$ \\
& Male & 3 & $21.0 \pm 6.9$ & $17-29$ \\
Juvenile & Female & 2 & $12.8 \pm 1.8$ & $11.5-14$ \\
Male & 2 & $13.0 \pm 2.1$ & $11.5-14$ \\
Adult & Female & 2 & $74.5 \pm 29.0$ & $54-95$ \\
Knapdaar & Male & 1 & 85 & - \\
Adult & Female & 1 & 48 & - \\
& Male & 2 & $62.5 \pm 3.5$ & $60-65$ \\
\hline
\end{tabular}

\footnotetext{
${ }^{\mathrm{a}, \mathrm{b}}$ Values in the same column and category differ at $P<0.007$.
} 
by weighing the organ full and empty (to the nearest $0.1 \mathrm{~g})$, using a Mettler PJ4000 electronic balance; $\mathrm{pH}$ was measured with a portable, battery-powered $\mathrm{pH}$ meter (Eutech, model EC-PH-10/01N); temperature of contents was measured with an electronic thermometer; and length of organ measured with a tape measure to the nearest $1 \mathrm{~mm}$. Dry weight of organ contents was obtained by drying in an oven at $70^{\circ} \mathrm{C}$ for 12 hours (constant weight).

For the fermentation studies, a $200 \mathrm{ml}$ sample of ingesta was quickly removed from the organ, placed in a $250 \mathrm{ml}$ glass bottle fitted with a rubber stopper containing a 20 guage stainless steel needle, and immediately placed in a $39^{\circ} \mathrm{C}$ water bath. A $10 \mathrm{ml}$ glass syringe was then attached to the needle and the amount of gas produced was noted every minute for $45 \mathrm{~min}$. Gas production was noted to cease between 30 and $50 \mathrm{~min}$, thus $45 \mathrm{~min}$. was chosen as a standard time for all incubations. As soon as each $10 \mathrm{ml}$ syringe was filled with gas, it was temporarily detached from the needle, the gas expelled and then reattached. No fermentation studies were conducted with the three samples from Knapdaar.

Contents of the caecum and colon were combined for counting and identification of protozoa. Two hundred $\mathrm{ml}$ of the fixed protozoa sample was washed through a set of sieves with an inner (110 $\mu \mathrm{m}$ pore size) and outer (37 $\mu \mathrm{m}$ pore size) chamber as described previously by Booyse et al. (2010). In brief; this washed sample was then allowed to stand for $30 \mathrm{~min}$ for the protozoa to settle out and the volume adjusted to $40 \mathrm{ml}$ by decanting the excess water. Two drops of Brilliant Green stain were added to the sample, which was then allowed to stand for $24 \mathrm{~h}$ before viewing microscopically (Dehority 1984). Three aliquots of $0.1 \mathrm{ml}$ from each sample were placed on separate microscope slides, fitted with a cover slip and examined with a standard light microscope fitted with a Panasonic camera, model GP220. In those cases where cells were over-stained so that internal structures were not visible, a drop of lactophenol was added to the slide to partially decolorize the cell. The protozoa were identified to species level and their individual concentrations determined by multiplying the mean for the three subsamples $(0.1 \mathrm{ml})$ counts by 10 , by 40 , and then dividing by 200 and multiplying by 2 to give the count per $\mathrm{ml}$ in the original contents.

Samples of caecum and colon fluids collected from the three additional animals at Knapdaar game ranch (Ellisras) were combined and fixed with an equal volume of $70 \%$ ethanol. Protozoa were counted both directly from a 1 to 2 dilution of caecum-colon fluid and after washing through the sieves as described above. For both the direct and washed samples, $0.025 \mathrm{ml}$ were placed on a slide and counted. The unwashed sample count was multiplied by $40 \times 2$ to give number of cells per $\mathrm{ml}$ of caecum/colon fluid. The washed sample was multiplied $\times 40 \times 40$, divided by 200 and multiplied by 2 to give cells per $\mathrm{ml}$ of caecum/colon fluid.

Statistical procedures, Student $t$-tests and correlations were carried out with MINITAB (1991). Significance level was set at 95\% $(P<0.05)$.

Weight of the adult males and females from Ditholo were significantly different (Table 1, Student $t$-test; $P<0.007$ ). Differences in weight of the males and females for the subadults and juveniles were not different $(P=0.687$ and 0.919 . respectively). Weight of both the subadult females and males were significantly lower than the adult animals ( $P=0.010$ and 0.001 , respectively). Subadult and juvenile body weights were not significantly different $(P=0.15$ for females and 0.18 for males). Because of the low numbers, no statistical analyses were made on the Northam and Knapdaar samples.

Physical parameters of the gastrointestinal tract and gas production for all animals at each location are presented in Table 2. For the 41 animals harvested from Ditholo, the $\mathrm{pH}$ values varied among the different sections, with the stomach $\mathrm{pH}$ values being acidic, ranging from 3.25 up to 5.51 , higher in the small intestine (6.82-7.55), lower in the caecum (5.72-6.74) and colon (5.69-6.58) (Table 2). The lower $\mathrm{pH}$ in the caecum/colon could be the result of microbial fermentation. Similarly, Goodson et al. (1988) measured caecum pH in ponies over a 24-hour feeding cycle and values ranged from approximately 5.8 at 7 hours after feeding up to 7.9 which occurred three hours after feeding. Values for the three animals from Northam showed a somewhat similar pattern except in the caecum, which measured slightly basic (Table 2).

Weight of organ contents for the Ditholo animals varied and was found to be highest for the colon, followed by the stomach, small intestine and caecum, respectively (Table 2). However, in the three Northam warthogs, weight of stomach contents was highest, then small intestine, caecum and colon. For all animals, dry matter was lowest in small intestine contents (1.0-2.4\%), higher in the caecum (4.4-11.4\%) and highest in the colon 
Table 2. Physical parameters and in vitro gas production by organ contents collected from African warthogs (Phacochoerus aethiopicus).

\begin{tabular}{|c|c|c|c|c|c|c|c|}
\hline $\begin{array}{l}\text { Site } \\
\text { Organ }\end{array}$ & $\begin{array}{c}\text { Average } \\
\text { animal weight } \\
(\mathrm{kg})\end{array}$ & Number/sex & $\mathrm{pH}$ & $\begin{array}{l}\text { Total organ } \\
\text { contents } \\
\text { (gram) }\end{array}$ & \% Dry matter & $\begin{array}{l}\text { Average ml gas/ } \\
\text { gram wet contents }\end{array}$ & $\begin{array}{c}\text { Density } \\
\text { (gram/ml) }\end{array}$ \\
\hline Ditholo & $\begin{array}{l}47.33 \pm 23.01 \\
(24.32-70.34)\end{array}$ & $\begin{array}{l}41 \text { total } \\
239,18 \delta^{+}\end{array}$ & & & & & \\
\hline Stomach & & & $\begin{array}{l}4.38 \pm 1.13^{b} \\
(3.25-5.51)^{c}\end{array}$ & $\begin{array}{c}1414.3 \pm 1018.7 \\
(359.6-2433.0)\end{array}$ & $\begin{array}{c}10.1 \pm 2.8 \\
(7.2-12.9)\end{array}$ & $\begin{array}{l}0.05 \pm 0.05 \\
\quad(0-0.5)\end{array}$ & $\begin{array}{l}0.62 \pm 0.18 \\
(0.44-0.80)\end{array}$ \\
\hline $\mathrm{SI}^{\mathrm{a}}$ & & & $\begin{array}{l}7.18 \pm 0.36 \\
(6.82-7.55)\end{array}$ & $\begin{array}{l}1083.5 \pm 573.5 \\
(509.96-1656.99)\end{array}$ & $\begin{array}{l}1.7 \pm 0.7 \\
(1.0-2.4)\end{array}$ & $\begin{array}{l}- \\
-\end{array}$ & $\begin{array}{l}0.89 \pm 0.17 \\
(0.17-1.06)\end{array}$ \\
\hline Caecum & & & $\begin{array}{l}6.23 \pm 0.51 \\
(5.72-6.74)\end{array}$ & $\begin{array}{c}340.8 \pm 340.3 \\
(0.6-681.0)\end{array}$ & $\begin{array}{l}8.1 \pm 3.3 \\
(4.4-11.4)\end{array}$ & $\begin{array}{l}0.38 \pm 0.14 \\
(0.24-0.52)\end{array}$ & $\begin{array}{l}0.51 \pm 0.15 \\
(0.36-0.66)\end{array}$ \\
\hline Colon & & & $\begin{array}{l}6.14 \pm 0.45 \\
(5.69-6.58)\end{array}$ & $\begin{array}{c}1995.5 \pm 1226.4 \\
(769.1-3222.0)\end{array}$ & $\begin{array}{c}10.8 \pm 3.42 \\
(7.4-14.2)\end{array}$ & $\begin{array}{l}0.34 \pm 0.12 \\
(0.21-0.46)\end{array}$ & $\begin{array}{l}0.68 \pm 0.17 \\
(0.52-0.85)\end{array}$ \\
\hline Northam & $\begin{array}{c}78 \pm 21.38 \\
(56.62-99.38)\end{array}$ & $\begin{array}{l}3 \text { total } \\
2 \circ, 10^{+}\end{array}$ & & & & & \\
\hline Stomach & & & $\begin{array}{l}5.47 \pm 0.59 \\
(4.88-6.06)\end{array}$ & $\begin{array}{l}2101.1 \pm 1055.8 \\
(1045.3-3157.0)\end{array}$ & $\begin{array}{l}8.5 \pm 1.0 \\
(7.5-9.6)\end{array}$ & $\begin{array}{l}0.08 \pm 0.46 \\
(0.34-1.26)\end{array}$ & $\begin{array}{l}0.53 \pm 0.32 \\
(0.21-0.85)\end{array}$ \\
\hline SI & & & $\begin{array}{l}6.8 \pm 0.30 \\
(6.5-7.1)\end{array}$ & $\begin{array}{l}1487.0 \pm 295.2 \\
(1191.9-1782.3)\end{array}$ & $\begin{array}{l}1.6 \pm 0.5 \\
(1.1-2.0)\end{array}$ & - & $\begin{array}{l}0.65 \pm 0.09 \\
(0.56-0.74)\end{array}$ \\
\hline Caecum & & & $\begin{array}{l}7.26 \pm 0.18 \\
(7.08-7.44)\end{array}$ & $\begin{array}{c}1120.7 \pm 452.7 \\
(668.0-1573.4)\end{array}$ & $\begin{array}{l}8.0 \pm 0.4 \\
(7.5-8.4)\end{array}$ & $\begin{array}{l}0.20 \pm 0.03 \\
(0.17-0.23)\end{array}$ & $\begin{array}{l}0.62 \pm 0.05 \\
(0.57-0.67)\end{array}$ \\
\hline Colon & & & $\begin{array}{l}6.29 \pm 0.2 \\
(6.10-6.49)\end{array}$ & $\begin{array}{l}509.1 \pm 120.3 \\
(388.8-629.4)\end{array}$ & $\begin{array}{l}8.3 \pm 0.7 \\
(7.6-9.0)\end{array}$ & $\begin{array}{l}0.21 \pm 0.03 \\
(0.18-0.24)\end{array}$ & $\begin{array}{l}0.57 \pm 0.01 \\
(0.47-0.67)\end{array}$ \\
\hline Knapdaar $^{d}$ & $\begin{array}{c}48 \\
57.5 \pm 3.5\end{array}$ & $\begin{array}{l}3 \text { total } \\
19,2 \delta\end{array}$ & & & & & \\
\hline
\end{tabular}

\footnotetext{
aSmall intestine. No. in vitro fermentations were done with small intestine contents.

${ }^{b}$ Mean \pm S.D. ${ }^{\text {cRange. }}$

${ }^{\mathrm{d}}$ No measurements other than weight were taken on these three warthogs.
}

(7.39-14.24\%). Stomach contents dry matter was similar to that in the colon (Table 2).

In general, gas production from stomach contents was minimal, probably because of the low $\mathrm{pH}$, which would inhibit microbial activity (Russell et al. 1979). Both caecum and colon contents produced considerably more fermentation gas, with higher production from the animals at Ditholo. Presumably the quality of the winter forage consumed by the Northam animals in June was lower than that of forages from Ditholo, which were available over a wide range of seasons. Across all organs and sites, density ranged from 0.17 $1.06 \mathrm{~g} / \mathrm{ml}$, averaging between 0.51 and 0.68 , except for small intestine contents from Ditholo, which averaged $0.89 \mathrm{~g} / \mathrm{ml}$.

Although the data are not shown for the Ditholo animals, temperature of the stomach contents averaged $35.7 \pm 3.1^{\circ} \mathrm{C}$, caecum contents $32.6 \pm$ $3.6^{\circ} \mathrm{C}$ and colon contents $32.6 \pm 3.2^{\circ} \mathrm{C}$. Organ lengths were: stomach, $216.3 \pm 56.2 \mathrm{~mm}$; caecum, $163.3 \pm 111.7 \mathrm{~mm}$; and colon, $869.5 \pm 538.5 \mathrm{~mm}$. Values obtained for the three animals from Northam were in the same range.
Correlations between the various parameters were calculated. Animal weight was significantly correlated with weight of stomach contents $(r=0.554, P<0.001)$; caecum contents weight $(r=0.620, P<0.001)$; and colon contents weight $(r=0.653, P<0.001)$. Animal weight was also significantly correlated with stomach and caecum length, but not colon length. Contents from all warthog stomachs were negative for the presence of protozoa. After completing the study of the samples from Ditholo and Northam, there was a question as to whether the procedure of washing the samples through sieves to remove particulate material may have retained some of the larger protozoa or allowed passage of the smaller protozoa (less than approximately 50-60 $\mu \mathrm{m}$ ). Pore size of the first and second sieves was $110 \mu \mathrm{m}$ and $37 \mu \mathrm{m}$, respectively. Thus, samples from three additional warthogs were collected from the Knapdaar game ranch in September 2010. Protozoa counts were made on the fixed and stained caecum/colon fluid and on the sample obtained after passing the caecum/colon fluid through the sieves. 
Table 3. Effect of washing caecum/colon fluid through sieves on the protozoa count in African warthogs (Phacochoerus aethiopicus) collected from the Knapdaar Game Ranch.

\begin{tabular}{|c|c|c|c|c|}
\hline $\begin{array}{c}\text { Warthog } \\
\text { no. }\end{array}$ & Protozoa species & $\begin{array}{l}\text { Protozoa } / \mathrm{ml} \\
\text { of caecum/ } \\
\text { colon fluid }\end{array}$ & $\begin{array}{c}\text { Protozoa/ml } \\
\text { in sieved sample } \\
\text { of caecum/colon fluid }\end{array}$ & $\begin{array}{l}\% \text { Recovery } \\
\text { of protozoa in } \\
\text { sieved sample }\end{array}$ \\
\hline \multirow[t]{7}{*}{1} & Charonina equi & 3680 & 960 & 26.1 \\
\hline & Blepharoconus krugerensis & 15200 & 2768 & 18.2 \\
\hline & Blepharosphaera intestinalis & 3040 & 448 & 14.7 \\
\hline & Megadinium aethiopicum & 640 & 80 & 12.5 \\
\hline & Telamodinium onyx & 1040 & 112 & 10.8 \\
\hline & Teratodinium sphaeredon & 480 & 64 & 13.3 \\
\hline & Total number $\times 10^{3}$ & 24.08 & 4.43 & 18.4 \\
\hline \multirow[t]{7}{*}{2} & Charonina equi & 4640 & 1104 & 23.8 \\
\hline & Blepharoconus krugerensis & 16160 & 2336 & 14.4 \\
\hline & Blepharosphaera intestinalis & 3520 & 640 & 18.2 \\
\hline & Megadinium aethiopicum & 1040 & 144 & 13.8 \\
\hline & Telamodinium onyx & 80 & 0 & 0 \\
\hline & Teratodinium sphaeredon & 0 & 0 & - \\
\hline & Total number $\times 10^{3}$ & 25.44 & 4.22 & 16.6 \\
\hline \multirow[t]{7}{*}{3} & Charonina equi & 1920 & 320 & 16.7 \\
\hline & Blepharoconus krugerensis & 19520 & 3984 & 20.4 \\
\hline & Blepharosphaera intestinalis & 2720 & 688 & 25.3 \\
\hline & Megadinium aethiopicum & 320 & 48 & 15.0 \\
\hline & Telamodinium onyx & 240 & 32 & 13.3 \\
\hline & Teratodinium sphaeredon & 240 & 64 & 26.7 \\
\hline & Total number $\times 10^{3}$ & 24.96 & 5.14 & 20.6 \\
\hline
\end{tabular}

These results are shown in Table 3, which clearly indicate that passing the sample through sieves markedly reduced the count of both large and small species of protozoa. Recovery of protozoa in the three sieved samples ranged between $10.8 \%$ and $25.3 \%$ and was not consistent across species or animal. On this basis it was concluded that the quantitative data obtained with the sieved samples would be completely confounded and thus only presence of the individual species will be reported. With the exception of Telamodinium onyx in Warthog-2, all species were observed in the washed samples and their occurrence in the individual animals is reported in Table 4.

The concentration of total protozoa in the three warthogs from Knapdaar, ranged from 24.08 to $25.44 \times 10^{3} \mathrm{cells} / \mathrm{ml}$. The only reported values for concentration of protozoa in the hindgut are from large herbivores, which are colon fermenters, while, as mentioned earlier, the warthog is a caecum fermenter (Hume \& Warner 1980; Dehority 2003). Reported protozoa concentrations in the caecum of the horse have ranged from $20-2230 \times 10^{3}$ cells $/ \mathrm{ml}$ and from $220-7060 \times 10^{3}$ cells/ml in the large colon (Adam 1951; Ozeki et al. 1973). Studies with ponies report values from $30-96$ and $60-133 \times 10^{3}$ cells $/ \mathrm{ml}$ in the caecum and colon of ponies, respectively (Goodson et al. 1988; Moore \& Dehority 1993).

The protozoan Blepharoconus krugerensis was consistently present in the highest concentration in all three animals from Knapdaar, comprising $63.1,63.5$ and $78.2 \%$ of the total ciliates in warthogs 1, 2 and 3, respectively.

In those animals harvested at Ditholo in 2003 and 2004, there was no obvious trend in occurrence of specific protozoa over the year. Telamodinium onyx was present in 40 of the 41 animals (95\%), Megadinium aethiopicum was present in 28 animals $(75 \%)$ and Teratodinium sphaeredon was present in only nine animals (24\%). Blepharoconus krugerensis was found in two animals (4.9\%), both of which were harvested in the summer (November). A species of both Cycloposthidae and Isotricha were observed in two separate animals at concentrations $<10$ cells $/ \mathrm{ml}$.

All three animals from Northam were obtained in the winter (June) and contained T. onyx and 
Table 4. Occurrence of protozoa in the caecum/colon fluid of the 47 African warthogs (Phacochoerus aethiopicus).

\begin{tabular}{|c|c|c|c|c|c|c|c|c|c|}
\hline \multirow[b]{2}{*}{$\begin{array}{l}\text { Locality \& } \\
\text { animal no. }\end{array}$} & \multirow[b]{2}{*}{$\begin{array}{l}\text { Age and } \\
\text { sex }\end{array}$} & \multirow[b]{2}{*}{$\begin{array}{c}\text { Date } \\
\text { collected }\end{array}$} & \multicolumn{6}{|c|}{ Protozoa/ml } & \multirow[b]{2}{*}{ Other } \\
\hline & & & $\begin{array}{l}\text { Telamodinium } \\
\text { onyx }\end{array}$ & $\begin{array}{l}\text { Megadinium } \\
\text { eathiopicum }\end{array}$ & $\begin{array}{l}\text { Teratodinium } \\
\text { sphaeredon }\end{array}$ & $\begin{array}{c}\text { Blepharoconus } \\
\text { krugerensis }\end{array}$ & $\begin{array}{l}\text { Blepharosphaera } \\
\text { intestinalis }\end{array}$ & $\begin{array}{c}\text { Charon } \\
\text { equi }\end{array}$ & \\
\hline \multicolumn{10}{|l|}{ Ditholo } \\
\hline Warthog 1 & ADM & Feb 03 & + & + & + & - & & & \\
\hline Warthog 2 & ADF & & + & - & - & - & & & \\
\hline Warthog 3 & SUF & & + & + & + & - & & & \\
\hline Warthog 4 & ADF & Mar 03 & + & + & - & - & & & \\
\hline Warthog 5 & ADM & & + & - & - & - & & & \\
\hline Warthog 6 & ADM & & + & + & - & - & & & \\
\hline Warthog 7 & ADF & & + & + & - & - & & & \\
\hline Warthog 8 & ADF & Apr 03 & + & + & + & - & & & \\
\hline Warthog 9 & ADM & & + & + & + & - & & & \\
\hline Warthog 10 & JUF & May 03 & - & + & - & - & & & $\begin{array}{l}\text { Isotricha } \\
\text { sp. }\end{array}$ \\
\hline Warthog 11 & ADM & & + & - & - & - & & & \\
\hline Warthog 12 & SDM & & + & - & - & - & & & \\
\hline Warthog 13 & SUF & Jun 03 & + & - & - & - & & & \\
\hline Warthog 14 & ADM & & + & + & - & - & & & \\
\hline Warthog 15 & ADF & Jul 03 & + & - & - & - & & & \\
\hline Warthog 16 & JUM & & + & + & - & - & & & \\
\hline Warthog 17 & ADF & & + & + & + & - & & & \\
\hline Warthog 18 & ADF & & + & + & - & - & & & \\
\hline Warthog 19 & JUM & & + & - & + & - & & & $\begin{array}{l}\text { Cyclopos- } \\
\text { thidae }\end{array}$ \\
\hline Warthog 20 & JUF & Aug 03 & + & + & - & - & & & \\
\hline Warthog 21 & ADF & & + & + & - & - & & & \\
\hline Warthog 22 & ADM & & + & + & - & - & & & \\
\hline Warthog 23 & ADF & Sep 03 & + & + & - & - & & & \\
\hline Warthog 24 & SUF & & + & + & - & - & & & \\
\hline Warthog 25 & ADF & Oct 03 & + & + & - & - & & & \\
\hline Warthog 26 & ADF & & + & + & - & - & & & \\
\hline Warthog 27 & ADM & & + & + & - & - & & & \\
\hline Warthog 28 & ADF & & + & + & - & - & & & \\
\hline Warthog 29 & ADM & Nov 03 & - & + & - & + & & & \\
\hline Warthog 30 & ADF & & + & + & - & + & & & \\
\hline Warthog 31 & ADF & Mar 04 & + & - & - & - & & & \\
\hline Warthog 32 & ADM & Apr 04 & + & + & - & - & & & \\
\hline Warthog 33 & ADM & & + & - & - & - & & & \\
\hline Warthog 34 & ADF & May 04 & + & + & + & - & & & \\
\hline Warthog 35 & ADM & & + & - & - & - & & & \\
\hline Warthog 36 & SUM & Jun 04 & + & + & + & - & & & \\
\hline Warthog 37 & SUM & & + & + & + & - & & & \\
\hline Warthog 38 & SUM & Aug 04 & + & + & - & - & & & \\
\hline Warthog 39 & ADF & Sep 04 & + & + & + & - & & & \\
\hline Warthog 40 & SUF & & + & + & - & - & & & \\
\hline Warthog 41 & SUF & Feb 05 & + & - & - & - & & & \\
\hline$\%$ Occurrence & & & 95.00 & 75.00 & 24.00 & 4.90 & & & 4.90 \\
\hline \multicolumn{10}{|l|}{ Northam } \\
\hline Warthog 1 & ADF & Jun 04 & + & + & - & + & & & \\
\hline Warthog 2 & ADM & & + & + & - & - & & & \\
\hline Warthog 3 & ADF & & + & + & - & + & & & \\
\hline$\%$ Occurrence & & & 100 & 100 & 0 & 66.70 & & & \\
\hline \multicolumn{10}{|l|}{ Knapdaar } \\
\hline Warthog 1 & ADM & Sep 10 & + & + & + & + & + & + & \\
\hline Warthog 2 & ADM & & + & + & - & + & + & + & \\
\hline Warthog 3 & ADF & & + & + & + & + & + & + & \\
\hline$\%$ Occurrence & & & 100 & 100 & 66.7 & 100 & 100 & 100 & \\
\hline
\end{tabular}

${ }^{\mathrm{a}} \mathrm{ADM}=$ adult male; $\mathrm{ADF}=$ adult female $; \mathrm{JUM}=$ juvenile male; JUF = juvenile female. 
A
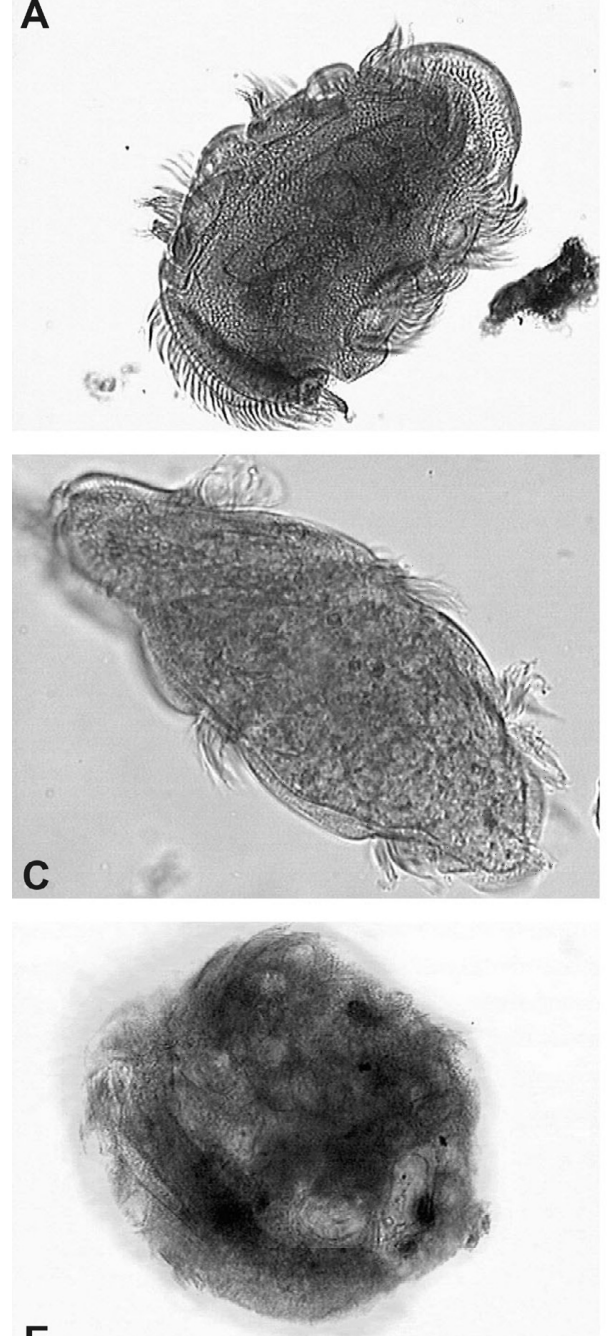

E

Fig. 2. Protozoa unique to the African warthog hindgut. A \& B, Megadinium aethiopicum, $160 \mu \mathrm{m}(\mathrm{A}, \times 200 ; \mathrm{B}, \times 400)$. C \& D, Telamodinium onyx, $90 \mu(\times 400)$. E \& F, Teratodinium sphaeredon, $100 \mu,(E, \times 200 ; \mathrm{F}, \times 400)$.

M. aethiopicum. However, T. sphaeredon was absent from all three animals. In addition, Blepharoconus krugerensis was present in two of the warthogs.

Photographs of the three protozoa species, T. onyx, M. aethiopicum and T. sphaeredon, apparently unique to the warthog, are shown in Fig. 2.

Of particular interest in the Knapdaar samples was the presence of the species Charonina equi and Blepharosphaera intestinalis. These two species were not found in any of the other 44 warthogs. Further investigation revealed that Knapdaar is fenced in with a three-metre high game fence surrounding the farm, which differs from the other game farms in this report. In addition to the normal game
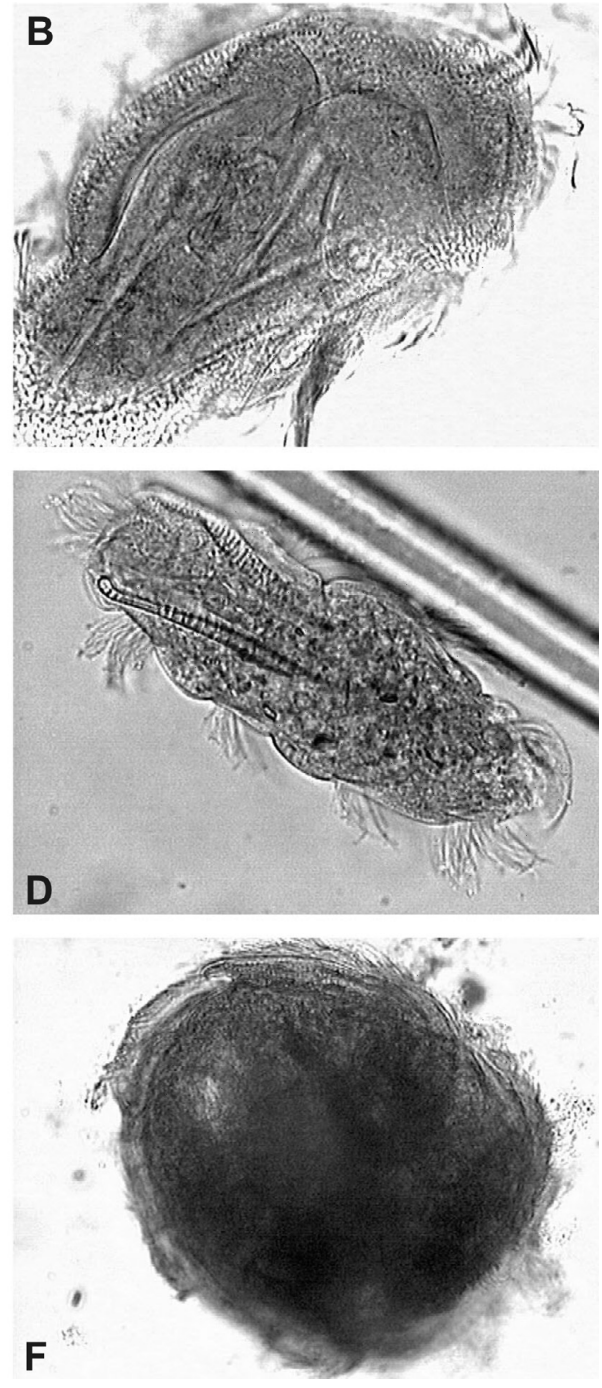

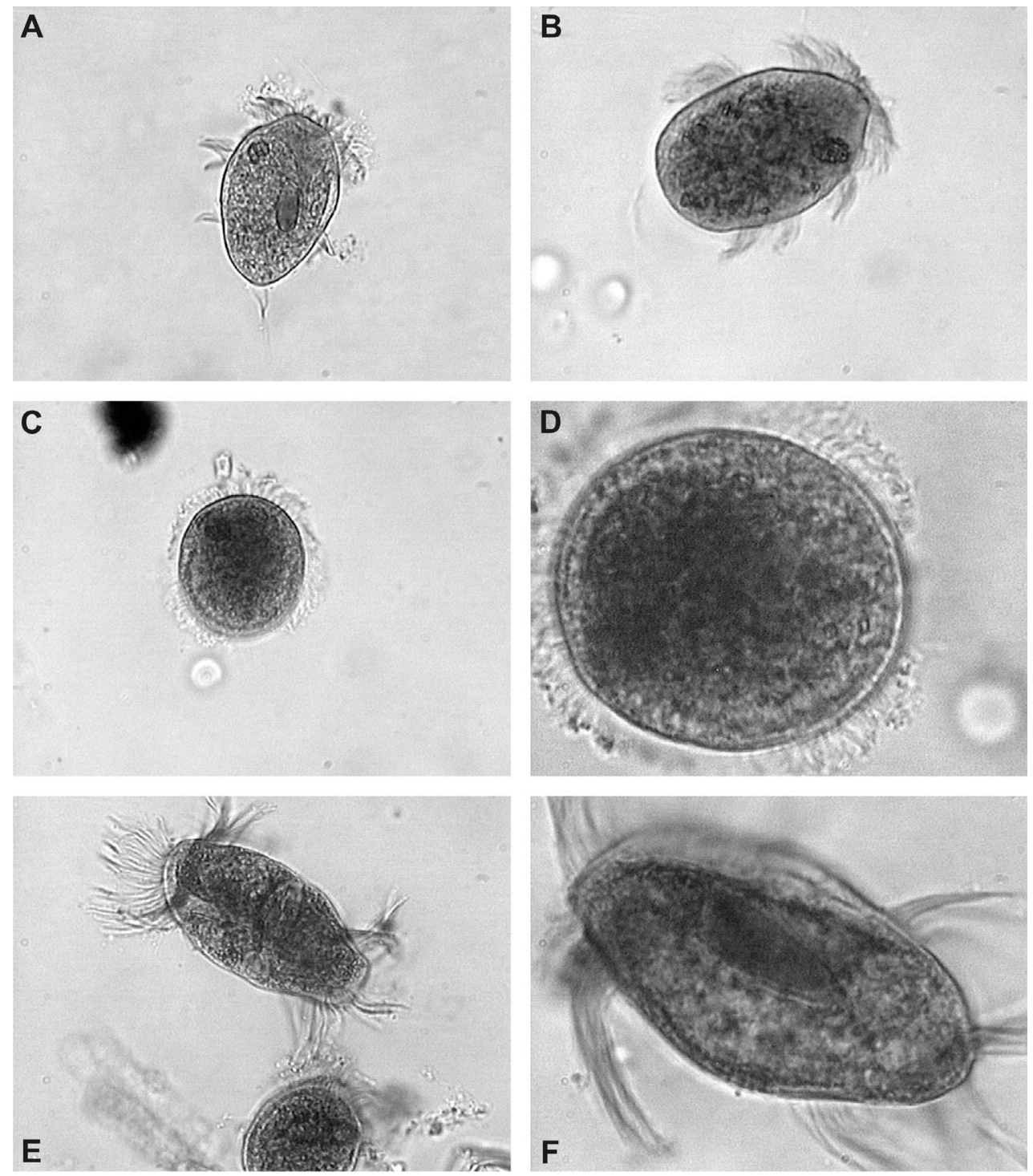

Fig. 3. Additional species of protozoa found in the African warthog hindgut. A \& B, Blepharoconus krugerensis, $55 \mu$ $(A, \times 400 ; B, \times 1000)$. C \& D, Blepharosphaera intestinalis, $37.5 \mu(C, \times 200 ; D, \times 1000)$. E \& F, Charonina equi, $62.5 \mu$ $(\mathrm{E}, \times 400 ; \mathrm{F}, \times 1000)$.

might possibly be explained by their intimate contact with the horses and zebra in the confined game reserve. Several previous reports have documented cross inoculation between different animal species. Dehority (1987) observed only rumen ciliate species in the hindgut of two capybara, which normally have a unique hindgut fauna. The capybara were housed in a zoo in the same pen with llamas, and It was suggested that the rumen protozoa were transferred to the capybara through a common water pool.
In contrast, no reports have been published indicating the presence of the three major protozoa species occurring in the warthog hindgut in any other host. Whether this is a function of environmental differences or simply a lack of cross inoculation between species is not clear. Inoculation of other herbivores, both foregut and hindgut fermenters, with warthog caecum contents would be of considerable interest.

In conclusion, considering only the three protozoa species unique to the warthog, percentage 
incidence in the present study was compared to the earlier report by Booyse et al. (2010), i.e. T. onyx, 96 and 100\%; M. aethiopicum, 77 and 47\%; T. sphaeredon, 26 and $12 \%$, respectively. It would appear that more variation in percentage composition occurred for those animals harvested in the present study. The samples collected at Knapdaar (Table 3) clearly suggest that protozoa concentrations in the warthog hindgut may be high under spring grazing conditions. However, the comparison with animals sampled in the winter season may be confounded since counts were determined on washed cecum/colon samples (Booyse et al. 2010). In addition to the three species of protozoa apparently unique to the hindgut of the warthog, the present data shows that other hindgut species, specifically several species normally found in the horse hindgut, can also become established.

\section{REFERENCES}

ADAM, K.M.G. 1951. The quantity and distribution of the ciliate protozoa in the large intestine of the horse. Parasitology 41: 301-311.

BOOYSE, D.G., BOOMKER, E.A. \& DEHORITY, B.A. 2010. Protozoa in the digestive tract of wild herbivores in South Africa. I: Warthogs (Phacochoerus aethiopicus). Zootaxa 2492: 63-68.

DEHORITY, B.A. 1984. Evaluation of subsampling and fixation procedures used for counting rumen protozoa. Applied and Environmental Microbiology 48: 182-185.

DEHORITY, B.A. 1987. Rumen ophryoscolecid protozoa in the hindgut of the capybara (Hydrochoerus hydrochaeris). Journal of Protozoology 34: 143-145.

DEHORITY, B.A. 2003. Rumen Microbiology. Nottingham University Press, Nottingham, U.K.

ELOFF, A.K. \& VAN HOVEN, W. 1980. Intestinal protozoa of the African elephant Loxodonta africana
(Blumenbach). South African Journal of Zoology 15: 83-90.

GOODSON, J., TYZNIK, W.J., CLINE, J.H. \& DEHORITY, B.A. 1988. Effects of an abrupt diet change from hay to concentrate on microbial numbers and physical environment in the cecum of the pony. Applied and Environmental Microbiology 54: 1946-1950.

GRAIN, J. 1990. Cytology and cytochemistry of rumen protozoa. Zoological Science 7, Supplement, 111-124.

HSIUNG, T-S. 1930. A monograph on the protozoa of the large intestine of the horse. Iowa State College Journal of Science 4: 359-423.

HUME, I.D. \& WARNER, AC.I. 1980. Evolution of microbial digestion in mammals. In: Digestive Physiology and Metabolism in Ruminants, (eds) Y. Ruckebusch \& P. Thivend, pp. 665-684. MTP Press, Lancaster, U.K.

LATTEUR, B. \& DUFEY, M.M. 1967. Reforme Systematique De La Famille Des Cycloposthiidae Porche, 1913. Acta Zoologica et Pathologica Antverpiensia 44: 125-139.

MINITAB REFERENCE MANUAL. 1991. PC Version, Release 8. Quickset, Inc., Rosemont, PA.

MOORE, B.E. \& DEHORITY, B.A. 1993. Effects of diet and hindgut defaunation on diet digestibility and microbial concentrations in the cecum and colon of the horse. Journal of Animal Science 71: 3350-3358.

OZEKI, K., IMAI, S., \& KATSUNO, M. 1973. On the distribution of the ciliated protozoa in the large intestine of horse. Tohoku Journal of Agricultural Research 24: 86-101.

RUSSELL, J.B., SHARP, W.M. \& BALDWIN, R.L. 1979. The effect of $\mathrm{pH}$ on maximum bacterial growth rate and its possible role as a determinant of bacterial competition in the rumen. Journal of Animal Science 48: 251-255.

VAN HOVEN, W.W. 1990. Cytological and general diversity in African animals. ln: Cytology and Cytochemistry of Rumen Protozoa, (ed.) J. Grain, Zoological Science 7, supplement: 111-124.

VAN HOVEN, W.W. \& GILCHRIST, FM.C. 1990. First record of ciliated protozoan endocommensals in the gut of bushpig. South African Journal of Wildlife Research 21: 1.

Responsible Editor: J.H. van Wyk 